\title{
Da leitura como se deserto: inscrição e sujeição significante
}

Piero Eyben ${ }^{\star}$

\section{Resumo}

O presente ensaio tem por objetivo discutir a leitura a partir da metáfora do deserto e de suas consequências metafigurativas (conforme a define Paul de Man) para a compreensão de uma teoria da leitura do texto literário. Ao ler três autores emblemáticos - Borges, Llansol e Vila-Matas -, pretendo desenvolver uma análise de seus modos particulares (à maneira de tropos) de se pensar a relação de poder entre sujeito da leitura e a sujeição pela leitura na escritura literária.

Palavras-chave: Leitura. Deserto. Metafiguração. Escritura. Sujeição.

\author{
Je vais sans peur par le désert \\ Théophile de Gautier \\ Call in thy deaths head there: \\ tie up thy fears \\ George Herbert
}

Tomarei aqui, de frente, uma leitura, aliás, três leitores que são, eles mesmos, o deserto - entre o imenso, grandioso e o estatuto da graça - da própria leitura. Então os digo, lendo suas leis: Borges, Llansol e Vila-Matas. O silêncio da escritura começa a falar; aguardo os tempos de cada letra, sem amabilidades. Em sentido estrito, escreve-se o estanque e lê-se ainda mais nessa indecisão sempre espelhadamente futura, infinda. $\mathrm{O}$ que se escreve é antes corpo das figuras que

\footnotetext{
Universidade de Brasília (UnB). Bolsista de Produtividade em Pesquisa do CNPq. Professor Doutor de Teoria da Literatura (Instituto de Letras - Departamento de Teoria Literária e Literaturas - Programa de Pós-Graduação em Literatura). Líder do grupo de pesquisa Escritura: linguagem e pensamento. E-mail: pieroeyben@gmail.com.
}

\footnotetext{
Data de submissão: fev. 2013 - Data de aceite: abr. 2013 http://dx.doi.org/10.5335/rdes.v9i1.3538
} 
constituem o próprio leitor, rigoroso. Assim, essa escrita permanece, na demora, habitando isso que se fecha sobre este texto.

Subterrânea, a figura do leitor permanece sendo aquela que não está jamais nos lábios do autor e, por isso, guarda-se como rigor - puis joia la mante (DANIEL, 1987, p. 62) - de seus silenciamentos e travessias. Ao abrigo de certo desejo de durar, o leitor permanece sendo uma temporalidade firme do ocupar-se, deixando-se marcado no tempo, que o faz sempre durar em contrair dívidas - na condição de Schuldigsein - assumindo-as todas. O que se retém nisso é, sem dúvida, certa figuratividade da leitura, uma vez que se está na leitura como aposta, ou, melhor, como propôs George Steiner, "cada livro contém uma aposta, um desafio ao silêncio, que só pode ser vencido quando o livro é aberto novamente" (2001, p. 15). O incomum do rastro, em silêncio, somente revela seu fechamento a partir do inolvidável pedido, pela abertura. O fascínio, sem precipitação, conduz todo texto a sua alternância, validando-se sempre como convite à areia, ao fulgor, à doença, ao sol da escritura.

O que se pode escrever/dizer sobre a leitura? Talvez o óbvio: é isso já uma leitura. O que se escreve entre a promessa e a cegueira? Velando-se, deixo para mais a frente, mais adiante tudo o que é lançado para além da visão: lugar interminavelmente perdido. A linguagem da leitura é sempre, assim, como que uma forma de deixar-se ler pelo que se lê, só no leito, na câmara. Dirige-se a uma nova realidade, essa da decisória marca de si mesmo. Em todos os indícios deixados, a leitura deve partir - e sempre se parte para o deserto - de certa disposição anímica intermédia entre sujeição e significante, entre o próprio e o alheio, assimetricamente (im)postos. Vê-se, desse modo, figurar como promessa um sempre atravessar - desde o início - entre a linha sem interrupções e a execução musical de seu legato. Assim, lê-se como a memória das palavras, enquanto se habita aquilo que pode ser retraído - absolutamente comprimido.

Nessa compressão, há uma (im)possibilidade em se perder de vista a relação escritural que estabelece a encenação permanente entre produção textual e leitor. Assim, este texto oferece-se às intrincadas relações entre o papel do leitor e o processo de escritura - retomando Steiner: "existe latente em todo ato de leitura consequente a compulsão de se escrever um livro em resposta" (2001, p. 20). Ao problematizar a dinâmica presente nas concepções teóricas de palavra literária, representação e alegoria, atém-se à figura do sujeito como aquele que se inscreve às margens do significado. Sendo assim, a escritura recobre toda relação entre sujeição significante (ação subjetiva que se deixa inscrever por rastros linguísticos) e linguagem literária (entendida como um processo de pluralização textual). Nesse sentido, traremos à cena de debate os textos de 
Jorge Luis Borges, Maria Gabriela Llansol e Enrique Vila-Matas com o intuito de compreender seus processos metafigurativos acerca da leitura e da escrita.

O primeiro movimento desértico que vem a mente é aquele da erosão eólica. Formam-se paisagens de vazio, deslumbramentos de areia. Aberto o caminho, freme-se um étimo para si, em reunião. O engajamento do texto, sobre si mesmo, faz de toda desordem uma busca arqueológica naquilo que permanece saindo-se à vista, esgarçando-se. $O$ próprio da palavra "ler", o impróprio da leitura, qual seria - du fond d'un naufrage? A borda do étimo guarda em si o artefato da erosão, segue-se corroendo. Legere diz "falar em voz alta", a doce eloquência dos rétores poderia ser levantada como um modo de reunir, religar - legato - musicalmente os partícipes na travessia do livro, como um pedido humano - penetrando-se pelo texto, sem fechar a boca. Ler, assim, é um compartilhamento da escritura - em suas próprias contradições com a letra -, páginas em punho, sebes de homens. Afastando-se as teias e areias da palavra, ler pode ser um remetimento de alguém, mas, e, talvez, sobretudo, uma projeção da leitura. Em se dizendo, em voz alta, legere, pode-se, a um só tempo, dizer aquilo que se fala, a todos. Em grego, um verbo: $\lambda \dot{\varepsilon} \gamma \omega$ ("dizer, falar, recolher, escolher, deitar, fazer deitar"). Assim, dizer o dia, pela voz que participa da escritura. Ler é sempre uma atividade dupla, solitariamente dupla, na qual se provoca o vazio da linguagem a ser continuado por um outro mais além. $\mathrm{O}$ próprio de ler é, com isso, uma erosão que faz engajar tudo o que fala e faz deitar - pois há sempre uma erótica da leitura - a continuação do corpo do texto.

Muito além de toda comunicação, ler não pode ser apenas decodificação, decifração de um corpo - seja degradado ou esplendoroso -, mas é antes de tudo o envolvimento do pedido - permitido em voz alta - para se compreender o silêncio. $O$ lugar no texto que exige o encontro não é um abrigo, mas, sobretudo, uma habitação do dizer e da palavra (de certa racionalidade), no $\lambda$ ó pode haver uma renúncia entre aquilo que está inscrito sobre a folha e aquilo que será inscrito sob o sujeito. Nesse abrigo perdido, a habitação do leitor promove-se em meio ao corpo alto da voz, mas também na longa cisão que alicerça certo deitar fora do audível, in diuturno silentio, diria Santo Agostinho a propósito de Ambrósio. Compreender o silêncio pela emissão de sons parece ser o paradoxo da biblioteca na antiguidade. Assim, é com Santo Ambrósio, segundo as Confissões de Agostinho, que a possibilidade de perscrutar o obscuro inicia seu caminho, num júbilo do espírito. Confessa-se a experiência: sed cum legebat, oculi ducebantur per paginas et cor intellectum rimabatur, vox autem et lingua quiescebant (VI, 3) ${ }^{1}$. Deslizando sobre as páginas, a leitura deixa de ser marca da eloquência e torna-se uma forma de repouso, um modo de o silêncio fazer-se como descanso da voz e aventu- 
ras sobre a obscuridade. Sua própria voz e língua, mudas, enquanto todos os "personagens" falam dentro das páginas. Ler silenciosamente é, portanto, uma cisão que faz a permanência do encontro procurar sua habitação. Enquanto se ocupa da escritura, a leitura pode tornar-se seu outro lado, da indecisão. Ou, melhor, o que é o deserto sem a erosão eólica?

Deserto é, também, o lugar da tentação. O mito cristão coloca no abandono a prova da palavra - em sagração. Inteiramente construído na experiência com a linguagem, o leitor clama em voz

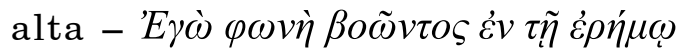
(João, 1: 23) - seu silêncio da hora, marcando-se quase como profecia inaudita daquele vazio anterior a si mesmo, buscado apenas nas páginas silentes ali prostradas. Porém, além das palavras proferidas, para fora da pronúncia e do silenciamento da escritura, o deserto como tentação do lugar conduz a compreensão do ato de ler a uma inscrição da lei (de uma nova lei?). A inscrição inicial - judaica - com o deserto revela-se como a fome para a terra prometida, como a provação do êxodo para a liberdade da escravidão. Lucas conta que Jesus passa pela mesma prova judaica, para reinscrever uma lei. Não se corre mais contra a sujeição despótica, mas se passa "quarenta dias sendo tentado pelo diabo" -

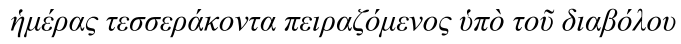
(Lucas, 4: 2) - como ato de cisão e unção. Da fome e da tentação pode-se pensar a leitura como pertencente à lei, essa inscrição que ultrapassa a fome, o pão - como propõem as falas em Lucas:

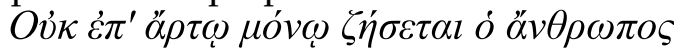
(Lucas, 4: 4). O homem, mais do que o pão, espera a declaração. Homófono ao verbo dizer, em grego, é o verbo delegar - promulgar a lei - em latim. Assim, pela tentação, retomo o étimo - também um abandono - da voz que delega as incumbências. O verbo latino "lego" encarrega-se de promulgar essa negativa do personagem no mito cristão: "não só de pão". Pelo pão, a legalidade da leitura revela-se como aporia da autoridade do texto, redistribuindo-o para além da função autoral. Na marginália das páginas, o leitor também assina.

A projeção da leitura recolhe-se, assim, em meio à tentação desértica, à autoridade que deve sempre ser pensada como indecisão. Não há leitura em que estejamos completamente isolados, dentro da própria justiça e dignidade da lei. Restando a borda do livro ao leitor, pode-se fazer dela o bordo - simétrico - que mantém o navio em prumo. Jacques Derrida propõe, em Força de lei, em termos de aporia, a compreensão da justiça como dubitibilidade, em rastros, ou, melhor, em suas palavras:

[...] (a memória da indecidibilidade deve conservar um rastro vivo que marque, para sempre, uma decisão como tal), ela [a prova da indecidibilidade] já seguiu novamente uma regra, uma regra dada, inventada ou reinventada, reafirmada: ela já não é presentemente justa, plenamente justa. Em nenhum momento uma decisão parece poder ser dita presente e plenamente justa. É por isso que a prova da indecidibilidade [...] nunca é passada ou ultrapassada, não é um momento superado ou revelado (aufgeho- 
ben) da decisão. O indecidível permanece preso, alojado, ao menos como um fantasma, mas um fantasma essencial em qualquer decisão, em qualquer acontecimento de decisão. Sua fantasmaticidade desconstrói do interior toda garantia de presença, toda certeza ou toda pretensa criteriologia que nos garantia a justiça de uma decisão (DERRIDA, 2007, p. 47-8).

Desse modo, o fantasma da justiça da lei promulgada - precisa ser pensado como apenas vindo "de outro como singularidade sempre outra", como propõe Derrida (2007, p. 49). Em termos desse contrato, não há decisão plenamente justa porque não há garantia plena de presença - mais à frente do pão - que faça, em certo, proferir um legado, que revele. Há, assim, um movimento dessa escritura, que marca a movência do pensamento, da invalidação de toda lei. Mesmo assim, a leitura pode ser uma lei, permanece sendo - na tentação - essa lei proferida e enviada, como uma embaixada da linguagem. A solidão da leitura promove a perda da autorictas do autor e coloca-o na posição horizontal - do leito do leitor - em se poder ter e roubar palavras. Assim, a leitura é uma lei, por ser já uma regra - não apenas indícios -, mas que nunca quer ser uma decisão reveladora e, com isso, deve permanecer um acontecimento fantasmal. Que leis são pensadas no leito? Quem se submete a distorcer os caminhos da palavra? A linguagem do leitor promulga seu silêncio e faz surgir seu processo - seu contrato - infindo com o texto.

Em A farmácia de Platão, Derrida inicia dizendo que o texto deve ocultar a lei de sua composição. O exergo propõe que todo texto estaria entre a cerzidura $\mathrm{e}$ a bofetada. Assim, nessa ilusão da tessitura, o leitor pode ir "regenerando indefinidamente seu próprio tecido por detrás do rastro cortante, a decisão de cada leitura" (2005, p. 7). A ordem em jogo seria o jogo, ele mesmo, desatando os olhares daquilo que faz ou tem a linguagem. No deserto, toda voz é antes inaudita, como todo escrito preso na garrafa. O limite do espaço é sempre pensado em termos da força aplicável à manutenção e ao cumprimento da lei. Assim, se o espaço da leitura é uma aporia da presentificação de sua própria lei, a violência do ato é maior na outorga de seus fios, de suas formas de descoser para arrematar mais esse dia de leitura. Por mais devastado e negativo que possa parecer o deserto, há nele um limite espacial inalcançável aos olhos, à vista do saber. Nada se desperdiça da linguagem, contudo o leitor atira-se sempre na busca aventureira desse deslimite dos próprios fios.

Retomo: "não apenas de pão". E o que mais no deserto? A leitura dispersa-se em devir constante com o texto. Seus rastros são do campo do enganar, que provém do pedido. Entre a promessa e a cegueira, as estantes a rasgar, pela escritura. $\mathrm{O}$ percurso é passagem que marca o tentar, o tocar. Trata-se de molestar o corpo, esse tecido de dias. $\mathrm{O}$ pão ataca, como pedras podem atacar certos pecados. Sabe-se, ainda, que toda leitura seja um gesto, trágico. Como trágico, deve consumar-se pela $\dot{\alpha} \mu \alpha \rho \tau i \alpha$ : a lei fatal do erro, da 
falha. Falham-se os limites e está-se mais além da regra econômica proposta por Umberto Eco - "termos econômicos da interpretação" (2005, p. 58). Dessa forma, num rastreamento da tentação, 0 leitor precisa falhar - cometer-se o $\pi$ á $\theta$ os - para que os significados não sejam como forças imputáveis da lei. A leitura é sempre uma hermenêutica, que se pode contradizer, que se pode propor além da interpretação. Jonathan Culler, em sua defesa da superinterpretação, propõe uma tática de ler que é, ela mesma, uma falha. Positivamente, a superinterpretação "enfatiza que o significado é limitado pelo contexto - em função de relações internas ou entre textos - mas que o contexto em si é ilimitado: sempre existirão novas possibilidades contextuais a serem apresentadas, de modo que a única coisa que não podemos fazer é estabelecer limites" (CULLER, 2005, p. 143). Assim, como apenas o pão? Em Lucas, Cristo não cede à tentação do desvínculo por aguardar a declaração. $\mathrm{O}$ leitor também não cede, apenas aguarda o ilimitado de seu fim.

Paul de Man, lendo Proust - que faz seu personagem Marcel ler todo o tempo -, propõe um acesso às metáforas da leitura. Em sua proposta, apresentada em Alegorias da leitura, ele diz: "a narrativa é a metáfora do momento, assim como a leitura é a metáfora da escrita" (1996, p. 86). Nesse sentido, para de Man, a compreensão figurativa da leitura - em seu oximoro disjuntivo entre "leitura esteticamente receptiva e a leitura retoricamente consciente" (1996, p. 90) - repousa sobre a aporia dos limites. O deserto pode estar para fora da fronteira, mas é, ele mesmo, sua fronteira habitável. O sentido de se ler é poder fazer da escritura o excesso, e não apenas resignar-se com o pão fruitivo de uma má leitura. O leitor existe, no texto, para ser a disjunção, a derrubada.

A leitura é reunião nos limites do esparso. Todo ato do livro apenas pode ser pensado em sua infinitude, que é também desértica declaração. Afirma-se, com isso, o espaço de uma linguagem na qual o significante pode reinscrever o leitor, imputando-lhe um poder, ao mesmo tempo em que ele se obriga a redistribuir seus dons. Eleger a memória das letras como ato é colocar-se nessa espera que constitui a obra, como porvir, e o leitor como agente dessa projeção futura. Maurice Blanchot, lendo Mallarmé, escreve: "a obra é a espera da obra. Somente nessa espera se concentra a atenção impessoal que tem por vias e por lugar o espaço próprio da linguagem" (2005, p. 352). Assim, aguarda-se o ato do livro como concentração do testemunho a ser dado. Nesse espaço, que pode ser a própria folha, está o tempo que prolonga a nomeação, o perfazimento. Reúnem-se, nesse espaço - quase utópico - da leitura uma impostura de lei e de dizeres, o amargo de ter-se livre, os livros à mão. Jorge Luis Borges, em "Mis libros", desponta sua escrita como artefato das posses de sua própria leitura: 
No sin alguna lógica amargura pienso que las palabras esenciales que me expresan están en esas hojas que no saben quién soy, no en las que he escrito (2007, p. 134).

A expressão do sujeito desatina-se na amargura do pensar que a obra impessoal - não sabe de quem se trata, do tempo que macula essa leitura, como escritura nas folhas que o perscrutam. A alternativa é legar - participando da lei - à imaginação uma possibilidade infinda de hospitalidade, no inóspito do texto. $\mathrm{O}$ deserto das folhas - alvura branca de sol - deve permanecer como ramos para o leitor "que sus sueños sigan ramificándose en la hospitalaria imaginación de quienes ahora lo cierran" (BORGES, 2007, p. 93). Os lugares do sonho e da hospitaleira imaginação são, por princípio, uma alternativa para dar vias à linguagem, como espaço em que aconteça o leitor. Assim, aguardam-se, no impessoal, as possibilidades mais além de um posfácio, de um epílogo. A posição do leitor deve ser constitutiva desse deserto, e Borges nos oferece uma matéria-prima: a areia.

Inútil reafirmar a fama borgiana das construções infinitas. Esse fato é tão marcadamente percebido em sua obra, tão evidente que passaria por obviedade a noção arenosa de literatura que importa aqui. Vamos ao cultivo do selvagem. O compulsivo colecionador de Bíblias e solitário habitante da calle Belgrano é a primeira figura desse deserto da leitura. Todos conhecem a história: o homem recebe um estrangeiro misterioso que o vende (em troca da aposentadoria e da Bíblia de Wiclif) El libro de arena, amostra monstruosa da exponencialidade, que acaba, de fato, aterrorizando e consumindo o comprador; ele, então, resolve se livrar da diabólica aquisição na Biblioteca Nacional da calle México.

A imagem do livro de areia é, sobretudo, a imagem da impossibilidade que revela o temor do espaço infindo de areia e da mutação temporal da areia no objeto livro. Disseminando-se nas faculdades de percorrer o espaço das páginas, o leitor consome-se e torna-se "prisionero del libro" (2007, p. 90), do mesmo modo que a areia é prisioneira na ampulheta. A precisão desse imaginário coloca-se como deslocamento da permanência, em outras palavras, a presença do leitor constrói-se no transporte de uma imagem a outra que se monta na erosão e na tentação desértica. Assim, é em sua ausência mascarada que o leitor intenta ler o que não está lá. O temor do personagem borgiano é uma identificação total - mesmo no mesmo - do leitor com a matéria constitutiva do livro, a areia. Sendo tão ausente e fugitiva quanto o leitor, tão infinita quanto ele, a areia escorre pela experiência sempre única da leitura - como bem adverte seu vendedor: "Mírela bien. Ya no la verá nunca más" (BORGES, 2007, p. 88) - e promove uma abertura não mediada à vontade, ao transportar-se eterno de um estar exterior à possibilidade de controle desse infinito. O leitor tem uma espécie de madrugada intranquila na qual é 
preciso crer na verdade, do abandono de um colar de corda de areias. Aqui há um problema: não se renuncia essa nova realidade, é preciso conviver com a ausência. $\mathrm{Ou}$, melhor, com Ricardo Piglia: "o que irrompe não é o real, mas a ausência, um texto que não se tem $\mathrm{e}$ cuja busca leva, como num sonho, ao encontro de outra realidade" (2006, p. 27). Essa outra realidade Borges adverte ser verídica em seu relato. $\mathrm{O}$ prisioneiro do deserto é um prisioneiro do tempo. A palavra revolve-se como habitação, tecida do exato, mas infinito. $\mathrm{Ou}$, como adverte o vendedor de Bíblias:

No puede ser, pero es. El número de páginas de este libro es exactamente infinito. Ninguna es la primera; ninguna, la última. No sé por qué están numeradas de ese modo arbitrario. Acaso para dar a entender que los términos de una serie infinita admiten cualquier número (BoRGEs, 2007, p. 89).

O livro guarda a visão do oriente - de uma Índia de sombras contaminantes que o personagem lê bem ao colocá-lo escondido entre as Mil e uma noites. Desse modo, o servirá o silêncio que perscruta essa infinidade de noites em que há o rio, o tapete, o sonho, o mapa do tempo. Todo termo põe termo à série infinda, assim como toda noite no deserto rompe o ilimitado do sol. O leitor assujeita-se e devém sujeito significante. Não se trata, portanto, de uma Weltanschauung, mas antes de uma abertura póstuma, uma exumação do assujeitado pelo tempo. $\mathrm{O}$ paradoxo do texto está no tempo "exatamente infinito" em que nenhuma parte pode ser formante de outra. Toca-se a au- sência como forma ao estar mais aquém de toda compreensão. Eis o deserto dessa areia: ao acaso, os livros revestem-se de números jamais repetíveis e, por isso, invisíveis para quem olha diretamente ao sol.

Maria Gabriela Llansol oferece-nos outra matéria para esse deserto: o fulgor. $\mathrm{O}$ brilho, o rebrilho advém do clarão de sol, do calor inóspito das vertigens e miragens. $\mathrm{O}$ fulgor é parte transcrita daquilo que se perde ao sonhar com a linguagem. Abrirei, assim, a sós, o oculto - que permanece queimando. Ainda há, nessa sujeição, outro jogo - limo submerso, pó rasteiro - o que rasgo, trepido, sublevo e circunscrevo entre o fulgor e a mancha, deixada estanque. Um tempo sempre aqui do significante reflore e desgasta, o que se diz em voz alta - $\lambda \varepsilon ́ \gamma \omega$ - pensamento, razão, palavra - גóyos - preclaro de alegoria desse intuito que lê - no sempre futuro do dito fulgurante.

Nos excertos do diário de 1981, "Um falcão no punho", Llansol inicia escrevendo: "Acumulo cenas fulgor/furor para Da sebe ao ser" (1987, p. 71). A forma do acúmulo, do rebrilho que pode ser transmitido. As cenas queimam o tempo, como o fulgor de sol, de sal da memória, de lugares, da linguagem, "nova realidade" pastoreada. O universo da escritura segue entre a palavra e seu lugar vazio, desolado, dado ao leitor, melhor, oferecido. Vultos no caminho, o corpo do leitor é um corpo subjetivo que se pode introduzir como tecido daquilo que 
o fulgor, de pradarias que rapidamente se esforçam em dizer, por escrito. Ou, ainda: "Diga-nos a aquiescência de que almejar com a escrita não é o mesmo que esbanjar no vazio a palavra" (LLANSOL, 1987, p. 75). Essa tela de palavras que é sua própria lei de ausência, escorada e escondida sob a forma do silêncio - na verdade, com gemidos ao fundo - na "nostalgia da figura ausente" (1987, p. 75). Ler esse acúmulo interpõe-se como uma experiência do esquecer-se de si mesmo, no universo da perda e da espessura da perda. A caminho, as palavras colocam-se como miragens produzidas - na rapidez - do fulgor: abrupta intensidade de ilusão. Toda leitura esconde uma morte própria da qual se diz um hoje. Não o absoluto da morte, no tecido marcado, mas a possessão da morte como experiência do próprio. A escritura tem por possibilidade o obscuro desse alumbramento. Intolerante, a recusa do texto em dizer somente pode se guardar dentro do rapidamente quente, do imediatamente brilhante, refletindo.

Há, assim, sempre uma pergunta obscena proposta ao leitor: qual é seu litoral? Onde o litoral, se só há deserto? Espreitam habitações que são elas mesmas a distância desse contínuo de séries. Esses interiores em que "há cenas fulgor que relampejam ao alcance da vista do viajante" (LLANSOL, 1982, p. 41), nas quais toda miragem é necessidade movente do rápido, instante. O litoral do leitor, seu ser em sebe, é "constituído de fragmentos dessas cenas de fulgor"
(1982, p. 42). A forma do pensamento, na escritura, modela-se enquanto desaparecimento e compensações do instante - todo fulgor é instantâneo; e há sempre uma manhã fraca. Sobreposto, todo desaparecimento é uma forma de ocupação, pois dá ao leitor "um corpo de fulgor e de penetração que se não confundisse com o físico, belo ou degradado. Um corpo integralmente feito de linguagem" (1997, p. 7). A escritura é pensamento nunca passado e, enquanto travessia, prepara o pedido do corpo, colocando-o no cerne desse litoral.

São os legentes de Llansol. A legalização da leitura - pois se tomam as "decisões de leitura" - compõe-se da escrita mais além do indício, naquilo em que o discordante - o polêmico - consubstancializa-se em um sonho de posse da linguagem. Ainda, entre o perigo do legente e a inscrição de seus textos, há a perda absoluta da autoridade do autor e, por que não, do texto: "porque há um leitor a escrever, e um leitor lendo - mas é sempre um legente com a sua inteligência, e um nó a desatar-se no olhar" (1997, p. 9). O nó no olhar, forma de inteligência - que se narra olhando, no vóos -, faz do leitor aquele que arrisca ser a borda do bordado, a risca desatando-se. Ocultos pela aparente fixidez do texto, os leitores promovem o "oscilante e trêmulo" (1997, p. 10) que faz de todo sujeito um separar-se do corpo e da imagem que se lhes guardam. Trata-se, por lógico, de uma manutenção do perecível. $\mathrm{Na}$ medida em que o texto "não te queima 
os lábios” (1997, p. 11), pois já está mudo desde Ambrósio, o texto permanece do refulgir da transitoriedade, do inaudito pelo deserto. Aliás, estar no deserto é estar perpétuo na manhã, que se rasga de palavras.

Todas são formas de fechar, encerrar com uma cerca - une séance de clôture - o texto de outrem. É, como propõe Llansol, "retirá-lo do horizonte inclinado onde flui entre legentes e procurar-lhe uma foz vertical " $(1997$, p. 13). Aguardo o vazio desse claustro, na clausura própria de sua originalidade. A sessão de encerramento faz presente 0 movimento denegativo da mortalidade, em que escrever é-me impossível. Há, sempre, uma cisão nessa foz vertical, no mais fundo da palavra faltante. Em que limite porta-se o envolvimento da repulsa da origem? Está-se na desembocadura, na garganta, que se coloca ao término, ao termo. A foz, íngreme, faz jorrar essa impossível escritura de fluências entre texto e legente para o caminho da escrita:

quem lê sabe que flutua uma linguagem dentro da linguagem.

quem lê sabe que, a nosso lado, a leitura desenha, com uma latitude selvagem inaudita, a grafia de uma outra história que, por vezes, se confunde com a nossa:

quem lê sabe que um livro é um não saber que, quando se desvenda, volta, por desejo, ao seu alvo imaginário

$[\ldots]$

o texto iniciado entrou nessa verdadeira vida que estava ausente

quem lê arrisca a visão continuando, arrisca a vida voltando

fez de nós legentes e companheiros, sabemos ler apenas a narrativa que sen- timos na prossecução da narrativa, sendo sentir, nessa experiência singular e partilhável, a forma maior de pensar (LlANSOL, 1997, p. 16-17).

Nessa linguagem, tudo resta flutuante, uma toda forma de dizer que na constância de sua verticalidade anuncia sua propriedade da linguagem. Nesse "sonho de que temos a linguagem" está o poder nominativo do estranho, do desabitado - da demora. Assim, a origem da linguagem no leitor funda-se como origem da própria leitura, no abandono do autor, nessa dissimetria. A vida mais verdadeira é a que se arrisca à leitura, pois a faz flutuar dentro da linguagem que é o próprio do sujeito. A agônica partilha entre companheiros faz desse sujeito sem subjetividade, que é o leitor, o possuidor de sua própria linguagem, ou, ainda, com Barthes: "le langage connaît un 'sujet', non une 'personne', et ce sujet, vide en dehors de l'énonciation même qui le définit, suffit à faire 'tenir' le langage, c'est-à-dire à l'épuiser" (2002, p. 42). Esgota-se a pessoalidade entre companheiros - comparsas de leitura para atingir-se no desejo da linguagem o conhecimento de seu assujeitamento. Esse gesto de inscrição do sujeito leitor reforça toda origem como degastada, pois se torna preciso na enunciação, no diálogo ininterrupto da escritura, na história daquela grafia que o vai escrever.

Jean-Luc Nancy, em "Um sujeito?", propõe: “o sujeito não é outra coisa senão o infinito identificado a uma precedência que se transpõe no infinito identificado a uma sucessão. Esse sujeito é sempre 
já acontecido e ainda sempre está para acontecer" (2001, p. 53). Nessa dinâmica de promessas, o sujeito poderia ser pensado como pertencimento à imensidão do deserto. $\mathrm{O}$ ato de postergar - $a d$ aeternum -, sua definição encontra-se sempre na possibilidade de dizer mais uma vez "eu sou"; e qualquer um o pode. $\mathrm{Na}$ presença do acontecimento da leitura, no entanto, nenhuma presença se faz como ato de existência, uma vez que os lábios estão mudos e a cabeça coloca-se na suposição de seu sujeito. Apresentar-se à leitura é propor-se ao ágon que constitui o cerne do sujeito enquanto tal. Sua forma permite-se entre o singular - a necessidade do Um para definir-se - e o múltiplo outro, particular, que se torna comum entre texto e linhas do texto. Deve-se, por isso, ir além da mera intromissão da singularidade do sujeito - em sua definição subjetiva - para que se possa de fato compreender o sujeito do leitor - no fulgor do deserto - como fundamento da significação, mártir da manutenção desses predicados. Nancy ainda propõe:

A significação é uma remissão: ela reenvia ao sentido pressuposto a uma pressuposição de sentido. Mas quando digo que o qualquer-um garante ou atesta o sentido, o sentido de ser qualquer um, é somente isso que o qualquer-um comporta. Quer dizer o qualquer-um se remete a ele mesmo, mas o "ele mesmo" não se encontra fora de sua atestação e isso não faz uma remissão. [...]. Isto é, o sentido não reportável a um sujeito de sentido, a um sujeito que poderia suportar o sentido e apresentá-lo de uma maneira ou de outra; significá-lo, e ainda mais demonstrá-lo. Mas, precisamente, o sentido é engajado pelo singular enquanto sentido singular do singular. Um sentido singular do singular é o que justamente não tem sentido, nem sentido pressuposto, nem passível de ser pressuposto (NANCY, 2001, p. 73).

Assim, como emissão, o sujeito da leitura deve se constituir para fora de toda demonstração do sentido, naquilo que sua singularidade (assêmica) o proporciona mais à frente de uma subjetividade pré-suposta. A renúncia da suposição do sujeito reside na possível unicidade desse sujeito. Dentro da leitura, no ato de ler, existe o "sujeito sobre o qual alguma coisa incide ou reincide" (NANCY, 2001, p. 31). Nessa sujeição, o sujeito é figura criada pela própria leitura que se apropria da linguagem, do sujeito e devolve-lhe o nó pensante daquilo que está em baixo de. Qualquer um pode supor-se a si mesmo, mas o sujeito na areia e no fulgor da leitura apenas é suposto como ordenador - operador - de seus próprios engendramentos. $\mathrm{O}$ "horror do vazio" que escreve Blanchot, em L'espace littéraire, é, desse modo, uma forma de completar-se não em busca de um sentido ao ego sum, mas de uma suplementaridade que expõe a ausência nesse desolado.

João Cabral de Melo Neto propõe "cultivar o deserto / como um pomar às avessas" (1994, p. 96). Assim, o fruto desértico - pedra, calhau, areia - torna-se matéria da experiência (poética) - destilar, fome, evaporação, madureza - na qual "resta a severa / forma do vazio" (1994, p. 97). Eis esse sujeito desértico da leitura: deixa-se a palavra por uma fome severa, por uma forma do vazio. 
Estanque de toda horta, a leitura não pressupõe, como muito já se disse, uma frutificação, uma polinização - de farinhas de flores -, mas um esvaziamento, certa esterilidade dos pressupostos subjetivos. Ao avesso, na devastação, o inacabamento de todo texto constitui-se por esse vazio que, sendo producente, é também marca da doença de ler, de passar a vida, a marca do tempo, lendo. Às multiplicidades de elementos do mesmo espaço podem, ainda, advir às experiências dentro desse espaço. No deserto, a mancha da linguagem pode ser pensada como figuras de calor, secura, areia, fulgores, sol, miragem, mas igualmente a experiência do deserto pode ser remontada como chaga. Propus, na descrição inicial desse ensaio, o deserto como lugar das erosões eólicas, mas também como o espaço da tentação e da promulgação da lei. Ora, são duas formas distintas de "cultivar o deserto", e ambas são igualmente formas do avesso. Por isso, Enrique Vila-Matas fornece um último que não pode ser o último - elemento a compor o deserto: o mal, a doença.

Desaparecer, eis a forma da doença trazida pela literatura. Em ato, o desaparecimento remete-se ao mal, que se apossa da solidão do escritor e de sua escritura no futuro. Vila-Matas inventa a doença da invenção por proliferação imaginária, o texto que intenta fazer do escritor um ser doente de imagens, lançado à neve da negação. A forma do diário é ironizada, hipostasiada em uma desolação que compõe o tecido esgarçado da escritura. Há, em El mal de Montano, uma espécie de busca pelo trabalho interior, pelo viver diário, que se escreve e lê como autobiografia imaginada e, portanto, já de si obscura e posta na doença, na chaga desse ermo literário. Talvez Vila-Matas, dentre todos os autores aqui sugeridos, seja o que mais reúna a hospitalidade entre textos, no diálogo dessas variabilidades. Sua indecidibilidade, mais radical até mesmo que a de Borges, conserva-se no ato entre o diário de escrita e a citação indiscriminada, hospedeira e parasitária (se tomarmos a ética de Hillis Miller), que constitui, como doença, uma verdadeira enciclopédia da negação.

Essa escritura pode ser empreendida como uma espécie de origem da linguagem do sujeito justamente por tornar-se ponto obscuro e esgarçado da sua entrada na irrealidade, ou, como diz o narrador de El mal de Montano:

Todo mundo se foi, e por alguns instantes fiquei vivendo ali, conhecendo uma estranha e muito paradoxal sensação, pois por um lado sentida que ficara vivendo no Museu da Literatura e, por outro, que, ao ficar só, não estava. Foi naqueles instantes de solidão e vida, que não o era, mas era vida, que eu decidi, em vista do sem-sentido da realidade daquele momento, entrar na irrealidade (Vila-Matas, 2005, p. 254).

Nesse sentido, compreende-se, pelo ermo da negatividade, o estar e não estar da experiência lida como literária. A decisão surge ao personagem como vinda do sem-sentido, da realidade como impossibilidade do sentido. $\mathrm{O}$ mal conversa, no trecho, com a ameaça infinda 
promovida pela literatura de destruição da experiência vivenciável como tal. Nesse lugar, um topo de vida e ficcionalidade, a solidão - erma por excelência - institui-se como a única condição do sujeito, sua única possibilidade frente à leitura, à escritura. Negar-se é manter-se no paradoxo, pois da decisão entre o sem-sentido e a irrealidade, o personagem prefere conduzir-se entre os arquivos desse museu, tomando-se como só, como linguagem para si. A reincidência do sujeito está no ponto em que ele, para manter-se no paradoxo, coloca-se como rastro, sempre adiado, de sua sujeição à representação, à enciclopédia que o diz, que o constrói.

A vida desértica do Museu de Tudo, do Museu da Literatura, é, de certa forma, uma espécie de pulsão por tudo guardar, mas também por tudo destruir. Dito de outro modo, está aí a forma do deserto como lugar da imensidão (da possibilidade toda) e da falência absoluta (da impossibilidade de manutenção). Em Mal de arquivo, Derrida aponta: "não haveria certamente desejo de arquivo sem a finitude radical, sem a possibilidade de um esquecimento [...] não haveria mal de arquivo sem a ameaça desta pulsão de morte, de agressão ou de destruição" (2001, p. 32). Há aí, portanto, um declínio na própria constituição da literatura como universo sempre lançado à derrisão do arquivo. A natureza do arquivar propõe sua negativa, sua pulsão negativa, percebida por Vila-Matas como fragmentação da realidade e dissolução do sujeito que entra lendo em cena - daí as inúmeras menções em El mal de Montano da figura emblemática de Hamlet-, que se inscreve no caminho desértico de, ao mesmo tempo, construir um museu, uma enciclopédia que tudo contenha do literário e, de outro lado, desconstruir essa enciclopédia, escrevendo-a como negatividade e ameaça, como finitude necessária.

$\mathrm{O}$ sujeito que sabe a resposta do desaparecimento é, nesse sentido, aquele que, ao ler ou escrever, defronta-se com a esgarçadura do texto. Nesse sentido, o sujeito é assujeitado pelo significante, pelo tecido reproposto como rastro de um local seguro, impondo-se, no desaparecimento, o deserto como lugar erosivo, tentador e de legitimação. O sujeito, Montano, marca-se como vida e cadáver de sua própria atividade de escrever no instante mesmo em que esse ato é uma leitura, um sulcamento da tradição autoral. Na transposição de poderes, aqui, os rastros da escritura permanecem como um duplo de rememoração, para o leitor: é parte da mnème (memória viva) e da hupomnème (rememoração, recoleção), como aponta Derrida em A farmácia de Platão (2005, p. 36). A escritura é um feixe de diferenças que, por transformações no desaparecimento, devasta o deserto, põe-se em ermo de sua irrealidade ao leitor. O mal da literatura - essa velha metáfora da escritura como perigo - é, também, um mal de arquivo, na medida em que o leitor-escritor lança-se, como aponta Vila-Matas, em uma "poética do 
abandono e da fuga" (2005, p. 259) para dar vazão a "seu gesto de encarnar em sua pessoa a literatura, protegendo-a de sua desesperada situação diante do abismo" (2005, p. 260). Os rastros deixados, assim, são marcas de paixões pela escritura, num impulso construtivo-destrutivo de lançar-se pelo ermo da literariedade, pelo ermo da vida, uma vez que "a leitura, a escrita procuram a vida, mas podem perdê-la precisamente porque estão inteiramente concentradas na vida e na sua própria busca" (VILA-MATAS, 2005, p. 309).

Lançar-se no abismo das páginas, no leite delgado do leito, na folha branca. Assim, nesse leito (lectus) desértico, busca-se o leite (lac) da leitura (legge$r e$ ), que se quer na união. Escritura e leitura, atividades póstumas e ausentes, atiradas - no mal, na peste - ao vazio de limites: cercanias do sem rumo, a borda deixada ao leitor, esse sempre vazio de assujeitar-se à margem. Mas, mesmo assim, faz bordo, coloca o texto em cena - uma sessão demasiadamente familiar e estranha -; nisto encarnam-se seus sujeitos duais: entre o qualquer-um e a suposição, de nem ser. Busca-se na obscuridade desse mal um caminho de areia - múltiplo infindo - e também um fulgor, ele próprio, o atentado à escritura, que te lança ao mundo outro, imaginário. Ainda, na escritura, como origem e negação, a marca do deserto, que pode ser o Egito, consolida-se, como se Platão o pudesse referir: o íbis voando, Theuth entrega a máquina da memória, a corrosão da memória. ${ }^{2}$
Ler é deserto. Deserto-me de ler. Trata-se de desertar. Ler é, assim, deserto; trata-se de desertar o sujeito de sua posição na presença para uma temporalidade muito mais distante das bordas, do controle aduaneiro. Desertar é sempre um abandono por traição; a leitura é traição, antibélica, esperada. Aguarda-se a saída do dizer; daquilo que, preclaro, se circunscreve entre o significante do sujeito e a sujeição dessa inscrição. Ao mesmo tempo, esse abandono é atirar-se no deserto (vox clamantis in deserto) esse demasiadamente sertão. $\mathrm{O}$ deserto deserta, assim mesmo como verbo. No mesmo fulgor, quente e seco, o deserto da leitura - e a digo com Proust, como intervenção, "no fundo de nós mesmos" (2001, p. 34) - é também um deserdar. Nega-se a voz dita $(\lambda \dot{\varepsilon} \gamma \omega)$, sua lei, sua sujeição de dizê-la. Entre herança e estabelecimento beduíno no deserto, há a perda sempre futura de seu sujeito na leitura. Não há infância da leitura, por ser sempre uma postumidade por vir, um lançar-se no deserto - e está aqui todo o êxodo, esse fora ( $\square \xi)$ do caminho ( $\square \delta$ ós) imputado a um povo - no qual o sol é marca da doença, pasmada de significantes, de rastros dessa voz que nunca é única. O senhor que fala, o colecionador, o diário transbordante, o pai ausente de seu filho nada mais são do que escritura da infância por vir, no fascínio, como no vento, como no leito de mim. 


\section{Reading as if a desert: significant subjection and inscription}

\section{Abstract}

This paper is aimed at discussing reading from the metaphor of the desert and its metafigurative consequences (as defined by Paul de Man) to the understanding of a theory of literary text reading. By studying three emblematic authors - Borges, Llansol and Vila-Matas -, I intend to develop an analysis of their particular modes (in the manner of tropes) of conceiving the power relations between the subject of reading and subjection through reading in literary writing.

Keywords: Reading. Desert. Metafiguration. Writing. Subjection.

\section{Notas}

1 Na tradução de J. Oliveira Santos, S. J. e A. Ambrósio de Pina, S. J: "Mas, quando lia, os olhos divagavam pelas páginas e o coração penetrava-lhes o sentido, enquanto a voz e a língua descansavam" (1973, p. 111).

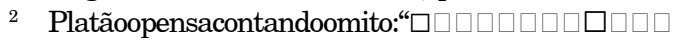

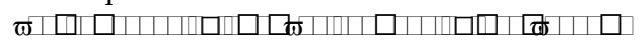

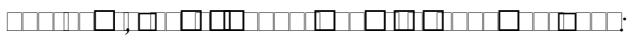

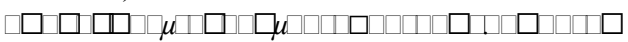

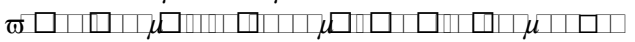

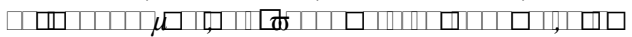
$\square \square \square \square \square \square \mu \mu \square \square \square$ "(Fedro,274c-d)[“Ouvidizerque havia nos arredores de Náucratis, no Egito, uma dessas divindades a quem os naturais da terra consagravam o pássaro denominado íbis. Esse demônio era conhecido pelo nome de Teute. Foi ele o primeiro a descobrir os números e o cálculo, a geometria e a astronomia, o jogo de gamão e dos dados, e também os caracteres da escrita" (trad. Carlos Alberto Nunes, 2007, p. 111)]. Nesse sentido, há uma relação entre o estatuto do sagrado, dos jogos, da geometria e da escrita, e, nesses elementos estariam os exercícios de memória, instaurados pela escritura.

\section{Referências}

AGOSTINHO, Santo. Confissões / De Magistro. Trad. de S. J. J. Oliveira Santos e S. J. A. Ambrósio de Pina. São Paulo: Abril Cultural, 1973. (Coleção “Os Pensadores”).

BARTHES, Roland. Oeuvres complètes tome III: 1968-1971. Paris: Seuil, 2002.

BLANCHOT, Maurice. O livro por vir. São Paulo: Martins Fontes, 2005.

BORGES, Jorge Luis. Obras completas: 1975-1985. Buenos Aires: Emecé, 2007. v. 3.

CAMPOS, Augusto de. Mais provençais. São Paulo: Companhia das Letras, 1987.

CULLER, Jonathan. Em defesa da superinterpretação. In: ECO, Umberto. Interpretação e superinterpretação. 2. ed. São Paulo: Martins Fontes, 2005. p. 129-146.

DE MAN, Paul. Alegorias da leitura: linguagem figurativa em Rousseau, Nietzsche, Rilke e Proust. Trad. de Lenita R. Esteves. Rio de Janeiro: Imago, 1996.

DERRIDA, Jacques. Mal de arquivo: uma impressão freudiana. Rio de Janeiro: Relume Dumará, 2001.

A farmácia de Platão. 3. ed. São Paulo: Iluminuras, 2005.

Força de lei. Trad. de Leyla Perrone-Moisés. São Paulo: Martins Fontes, 2007.

ECO, Umberto. Lector in fabula: a cooperação interpretativa nos textos narrativos. 2 . ed. São Paulo: Perspectiva, 2002.

Interpretação e superinterpretação. 2. ed. São Paulo: Martins Fontes, 2005.

LLANSOL, Maria Gabriela. Da sebe ao ser. Revista Colóquio/Letras, n. 69, p. 41-45, set. 1982. 
Um falcão no punho. Revista Colóquio/Letras, n. 97, p. 71-76, maio/jun. 1987.

. O sonho de que temos a linguagem. Revista Colóquio/Letras, n. 143/144, p. 5-18, jan. 1997.

MELO NETO, João Cabral de. Psicologia da composição. In: OLIVEIRA, Marly de (Org.). Obra completa. Rio de Janeiro: Nova Aguilar, 1994. p. 93-97.

NANCY, Jean-Luc. Um sujeito? In: WEIL, Dominique (Org.). O homem e o sujeito. Rio de Janeiro: Revinter, 2001. p. 25-74.

PIGLIA, Ricardo. O último leitor. São Paulo: Companhia das Letras, 2006.

PLATO, Phaedrus. Platonis Opera, ed. John Burnet. Oxford: Oxford University Press, 1903.

PLATÃO. Diálogos: Fedro, Cartas, O Primeiro Alcibíades. 2. ed. Trad. de Carlos Alberto Nunes. Belém: EDUFPA, 2007.

PROUST, Marcel. Sobre a leitura. 3. ed. Trad. de Carlos Vogt. Campinas, SP: Pontes, 2001.

STEINER, George. Nenhuma paixão desperdiçada. Rio de Janeiro: Record, 2001.

VILA-MATAS, Enrique. O mal de Montano. Trad. de Celso Mauro Paciornik. São Paulo: Cosac Naify, 2005. 